Article

\title{
Graphene Enhances Actin Filament Assembly Kinetics and Modulates NIH-3T3 Fibroblast Cell Spreading
}

\author{
Jinho Park ${ }^{1,2}$, Pavlo Kravchuk ${ }^{1}$, Adithi Krishnaprasad ${ }^{1,3}$, Tania Roy ${ }^{1,2,3}$ (i) and Ellen Hyeran Kang 1,2,4,*(D) \\ 1 NanoScience Technology Center, University of Central Florida, Orlando, FL 32826, USA; \\ Jinho.Park@knights.ucf.edu (J.P.); Pavlo@knights.ucf.edu (P.K.); adithiprasad@Knights.ucf.edu (A.K.); \\ tania.roy@ucf.edu (T.R.) \\ 2 Department of Materials Science and Engineering, University of Central Florida, Orlando, FL 32816, USA \\ 3 Department of Electrical and Computer Engineering, University of Central Florida, Orlando, FL 32816, USA \\ 4 Department of Physics, University of Central Florida, Orlando, FL 32816, USA \\ * Correspondence: Ellen.Kang@ucf.edu; Tel.: +1-407-823-2368
}

Citation: Park, J.; Kravchuk, P.; Krishnaprasad, A.; Roy, T.; Kang, E.H. Graphene Enhances Actin Filament Assembly Kinetics and Modulates NIH-3T3 Fibroblast Cell Spreading. Int. J. Mol. Sci. 2022, 23, 509. https:// doi.org/10.3390/ijms23010509

Academic Editor: Ana

María Díez-Pascual

Received: 18 November 2021

Accepted: 30 December 2021

Published: 3 January 2022

Publisher's Note: MDPI stays neutral with regard to jurisdictional claims in published maps and institutional affiliations.

Copyright: (C) 2022 by the authors. Licensee MDPI, Basel, Switzerland. This article is an open access article distributed under the terms and conditions of the Creative Commons Attribution (CC BY) license (https:// creativecommons.org/licenses/by/ $4.0 /$ )

\begin{abstract}
Actin plays critical roles in various cellular functions, including cell morphogenesis, differentiation, and movement. The assembly of actin monomers into double-helical filaments is regulated in surrounding microenvironments. Graphene is an attractive nanomaterial that has been used in various biomaterial applications, such as drug delivery cargo and scaffold for cells, due to its unique physical and chemical properties. Although several studies have shown the potential effects of graphene on actin at the cellular level, the direct influence of graphene on actin filament dynamics has not been studied. Here, we investigate the effects of graphene on actin assembly kinetics using spectroscopy and total internal reflection fluorescence microscopy. We demonstrate that graphene enhances the rates of actin filament growth in a concentration-dependent manner. Furthermore, cell morphology and spreading are modulated in mouse embryo fibroblast NIH-3T3 cultured on a graphene surface without significantly affecting cell viability. Taken together, these results suggest that graphene may have a direct impact on actin cytoskeleton remodeling.
\end{abstract}

Keywords: actin cytoskeleton; assembly kinetics; graphene; excluded area; cell spreading

\section{Introduction}

Actin is an essential cytoskeletal protein that promotes the reorganization of cellular architectures, thereby enabling cell morphogenesis, migration, and differentiation [1-3]. Actin monomers polymerize into double-stranded helical filaments in the presence of cations and ATP hydrolysis. [4-6]. Within cells, actin filament assembly dynamics are tightly regulated by various intracellular environmental factors, including cation interactions $[7,8]$ macromolecular crowding [9-11], and actin binding proteins $[6,12,13]$. Changes in the microenvironment have also been also shown to affect the actin cytoskeleton. Recent studies have suggested that exposure to nanomaterials, in particular carbon-based nanomaterials (i.e., single-wall carbon nanotubes (SWCNT), graphene oxide, and graphene), can modulate actin polymerization [14-18].

Graphene is a single layer of $\mathrm{sp}^{2}$ hybridized carbon nanomaterial that has served as a promising biomaterial due to its unique structural, mechanical, thermal, and electrical properties [19-22] as well as biocompatibility [23-25]. These properties render graphene an effective nanomaterial that can be used in drug delivery vehicles [26], biosensing [27], cancer therapy [28], and scaffolds for tissue engineering [29]. Increasing usage of graphene for cellular applications requires understanding how the physicochemical properties of graphene affect biomolecular interaction, adsorption, and conformation [25], thus potentially affecting cellular processes. Given that graphene potentially interacts with the actin cytoskeleton, it is important to understand how graphene affects actin filament assembly dynamics for proper biomedical applications. 
Several studies have shown that graphene can alter the actin cytoskeleton at the cellular level indirectly through triggering the signaling pathway [30], producing reactive oxygen species (ROS) [31,32], and reducing ATP production [33]. Graphene has been shown to impact actin rearrangement in naive macrophages by enhancing cytokine and chemokine production, decreasing cell adhesion [30]. Accumulation of graphene nanoflakes on the cell membrane of Vero cells (monkey kidney cells) causes ROS production, followed by actin filament rearrangement [31]. Zhou et al. reported that upon cellular uptake, graphene nanoflakes disrupted the electron transfer in mitochondria and reduced ATP production, which may lead to impaired actin filament assembly in breast cancer cells [33]. In addition, a molecular dynamics (MD) simulation has shown that actin monomers adhere to graphene via weak interactions, including van der Waal forces, electrostatic interactions, and hydrogen bonding [34]. These interactions are not strong enough to dissociate two actin monomers compared to graphene oxide (GO) and reduced graphene oxide (rGO) $[16,17]$, of which functional groups on graphene oxide can form hydrogen bonds with oxygencontaining residues in actin [34], thereby inducing actin disassembly $[16,17]$. While the effects of graphene on the actin cytoskeleton have been reported at the cellular level, how graphene modulates actin filament assembly is not well established.

In this study, we investigate how graphene modulates actin filament assembly kinetics utilizing total internal reflection fluorescence (TIRF) microscopy imaging and bulk pyrene fluorescence assay. We hypothesize that the non-covalent interaction between actin and graphene may have a direct impact on actin filament assembly. We demonstrate that both pure graphene flakes and graphene surface enhance the average growth rates of individual actin filaments in a concentration-dependent manner. Furthermore, we demonstrate mouse embryo fibroblast NIH-3T3 cells seeded on the graphene surface exhibit stretched cell peripheral regions without incurring cytotoxicity, indicating the hydrophobicity of the graphene surface may modulate cellular morphology. Taken together, our study suggests that graphene can directly modulate actin assembly kinetics, thereby potentially modulating the actin cytoskeleton remodeling in cells.

\section{Results and Discussions}

\subsection{Graphene Flakes Affect Actin Filament Length without Hampering Polymerization}

We first evaluated the effects of graphene flakes on steady-state actin polymerization using TIRF microscopy imaging. We chose pristine graphene flakes rather than graphene oxide flakes or its derivatives since pure graphene flakes have well-defined hydrophilic and hydrophobic regions, demonstrated by a recent study [35]. We polymerized actin filaments (18-20\% Alexa-labeled) in the absence (control) or presence of graphene flakes $(0.5-20 \mu \mathrm{g} / \mathrm{mL})$, and then measured the steady-state actin filament lengths in the presence of graphene flakes $(0.5-20 \mu \mathrm{g} / \mathrm{mL}$ ) (Figure S1). The average filament lengths (control, $3.26 \mu \mathrm{m})$ significantly increased $(\sim 23.9 \%)$ with $5 \mu \mathrm{g} / \mathrm{mL}$ graphene flakes $\left(L_{a \mathrm{vg}}=4.04 \mu \mathrm{m}\right)$ where the filament length peaked among the range of graphene flake concentrations. At $10 \mu \mathrm{g} / \mathrm{mL}$ graphene flakes, similar lengths of actin filaments compared to controls were observed $\left(L_{a v g}=3.02 \mu \mathrm{m}\right)$, and $20 \mu \mathrm{g} / \mathrm{mL}$ graphene flakes reduced the filament lengths by $15 \%$ compared to controls. Next, we conducted bulk kinetic assays using pyrene-labeled actin to determine the effects of graphene flakes on actin polymerization (Figure 1). In the presence of graphene flakes, the pyrene fluorescence intensity increased in comparison to controls, indicating graphene flakes do not hamper the assembly of actin monomers into filamentous actin (Figure 1). The highest concentration of graphene flakes $(20 \mu \mathrm{g} / \mathrm{mL})$ was slightly delayed in reaching a similar maximum fluorescence intensity compared to controls. (Figure 1). These data indicate that graphene flakes result in modulation of filament lengths without hampering bulk actin polymerization. 


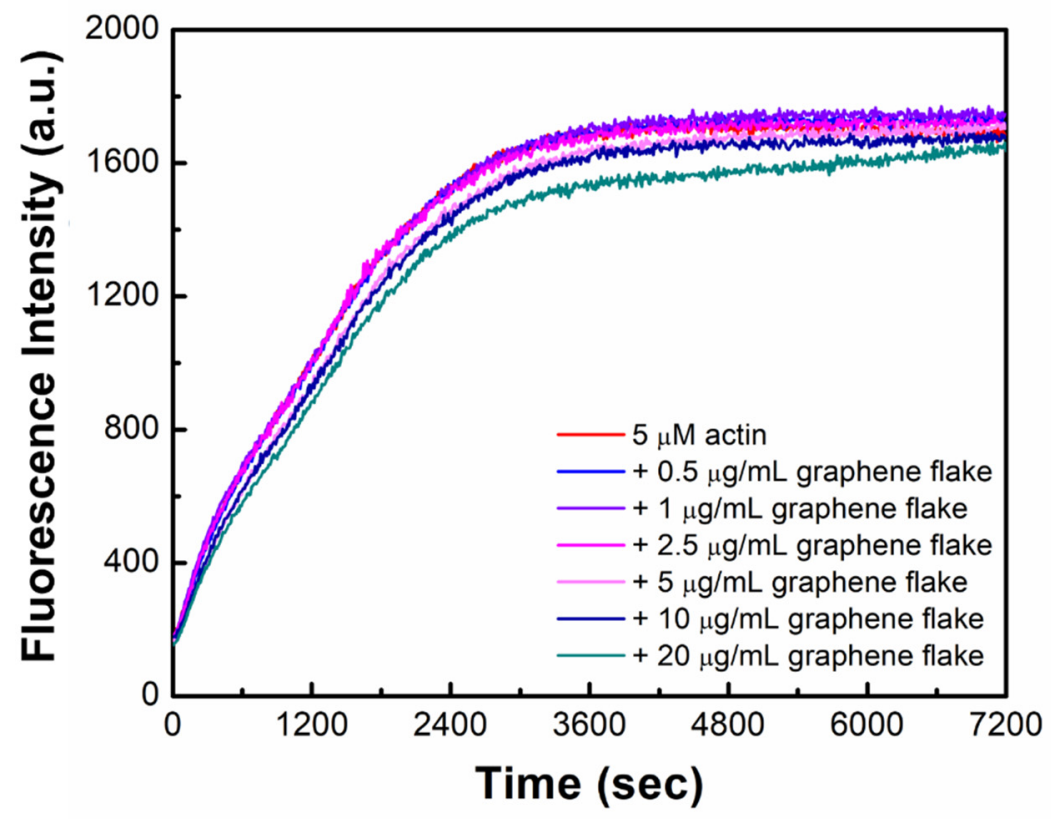

Figure 1. Graphene flakes do not hamper bulk actin polymerization. Actin $(5 \mu \mathrm{M}, 20 \%$ pyrenelabeled) polymerization in the presence of graphene flakes at varying concentrations $(0.5-20 \mu \mathrm{g} / \mathrm{mL})$ was monitored. Data are a representative from triplicated trials.

\subsection{Graphene Flakes Modulate the Rates of Actin Filament Elongation}

To determine how pure graphene flakes in solution affect actin filament assembly rates, we visualized the growth of individual actin filaments with varying concentrations of graphene flakes using a functionalized flow cell chamber (see Materials and Method for details). We polymerized actin filaments (18-20\% Alexa-labeled, $0.38 \%$ biotinylated) in the absence (control) or presence of graphene flakes $(0.5-20 \mu \mathrm{g} / \mathrm{mL})$. The presence of graphene flakes rendered faster actin filament elongation (Figure 2a,b, Videos S1-S7). Without graphene flakes, the elongation rate of actin was $11.40 \pm 1.97 \mathrm{~nm} / \mathrm{s}(4.22 \pm 0.77$ subunits $/ \mathrm{s})$, which is a similar value with the previously reported value (3.9 \pm 0.4 subunits $/ \mathrm{s}$ [36]) (Figure 2c). A total of $0.5-5 \mu \mathrm{g} / \mathrm{mL}$ graphene flakes resulted in statistically significant increases in the average elongation rates up to $15.46 \pm 1.96 \mathrm{~nm} / \mathrm{s}$, which is approximately an $11-36 \%$ increase compared to controls. With $10 \mu \mathrm{g} / \mathrm{mL}$ graphene flakes, the extent of increase in elongation rate dropped to $13.96 \pm 1.96 \mathrm{~nm} / \mathrm{s}$ but was still significantly higher than controls ( $22 \%$ increase). With $20 \mu \mathrm{g} / \mathrm{mL}$ graphene flakes, the elongation rate did not show a significant difference $(11.79 \pm 1.70 \mathrm{~nm} / \mathrm{s})$.

Actin assembly dynamics are controlled by various physiological factors $[6,37,38]$. One such physiological factor affecting actin polymerization is macromolecular crowding that induces the excluded volume effect [10]. In a crowded environment, the volume accessible for actin monomers is excluded from the space occupied by macromolecules. The excluded volume effect increases the rates of reactions, including protein assembly and proteinprotein interactions $[39,40]$. The presence of crowding reduces the critical concentration of ADP-actin and enhances filament stability by reducing subunit dissociation $[10,41]$. The excluded volume effect is applied in three-dimensional materials, however, it can also exist in terms of two-dimensional materials because two-dimensional materials have an exclusion region around each particle, unless all particles overlap [42]. As graphene flakes exclude the region available for actin monomers, the critical concentration for actin may be shifted modulating the actin assembly kinetics. 


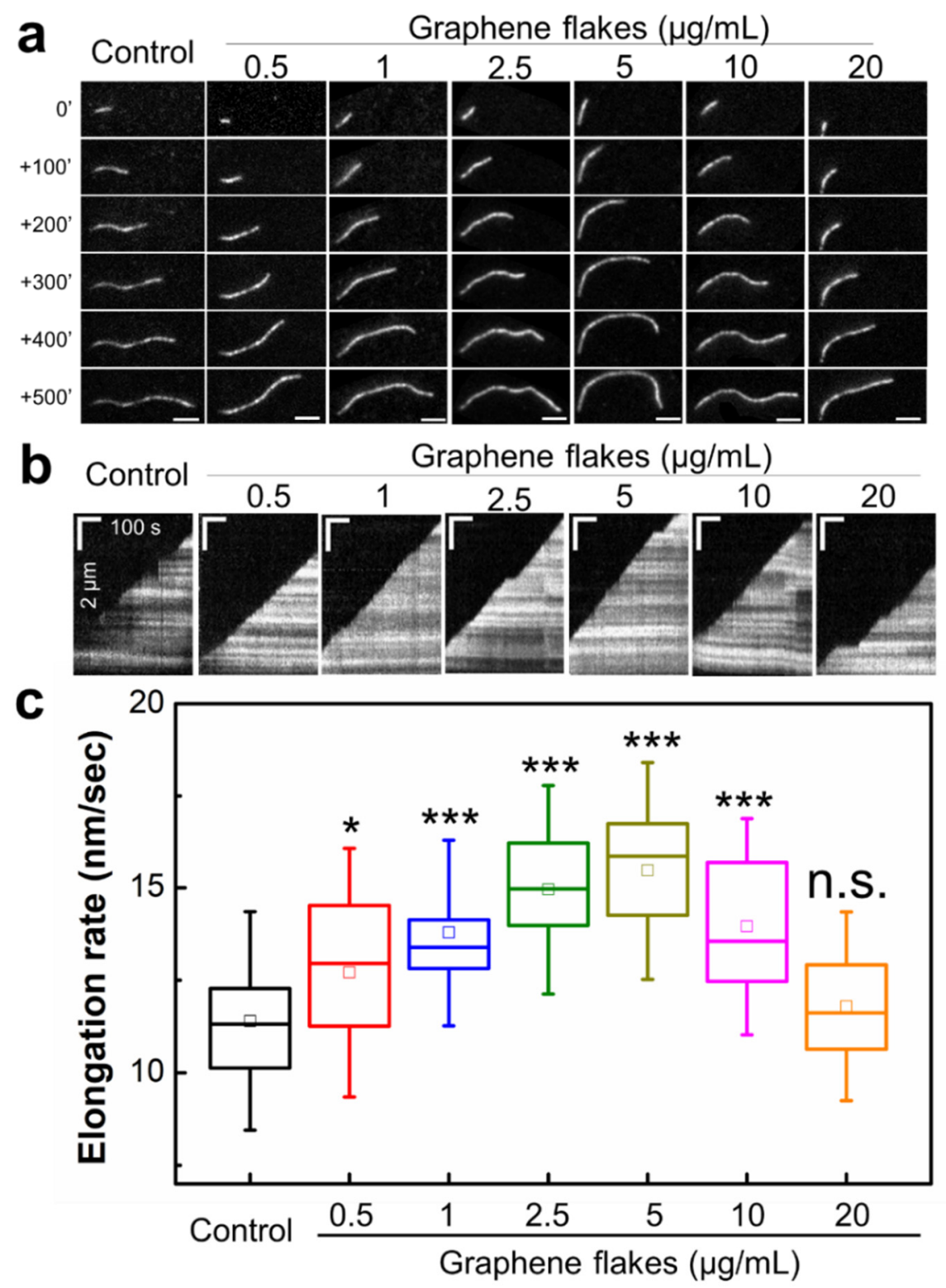

Figure 2. Graphene flakes modulate the assembly kinetics of individual actin filaments. (a) Representative total internal reflection fluorescence (TIRF) microscopy images of growing actin filaments in the presence of varying concentrations of graphene flakes $(0.5-20 \mu \mathrm{g} / \mathrm{ml})(\Delta \mathrm{t}=100 \mathrm{~s})$. (b) Linear kymographs of the growing filaments in the presence of graphene flakes. Alexa-labeled actin monomers were polymerized in a functionalized flow cell. Images of actin filaments were taken every $5 \mathrm{~s}$. Length scale bar (vertical) is $2 \mu \mathrm{m}$, and time scale bar (horizontal) is $100 \mathrm{~s}$. (c) The rates of actin filament elongation in the presence of graphene flakes at varying concentrations. The elongation rate was determined by the slope of actin filament length over time, and then converted to a function of time to $\mathrm{nm}$. The box represents the 25-75th percentile, whiskers indicate standard deviation (SD), and the middle square is the mean. Statistical analysis was performed using Tukey's test. $N=24-67$, n.s; not significant, ${ }^{*} ; p<0.05,{ }^{* * *} ; p<0.001$.

The observed reduction in actin polymerization at higher concentration of graphene flakes $(20 \mu \mathrm{g} / \mathrm{mL})$ can be explained by the location of two adjacent graphene flakes. The excluded area of two-dimensional materials depends on the relative angle between two particles [42]. The excluded area is minimized when two particles are in parallel or antiparallel (the relative angle between two particles is 0 or $\pi$ ) [42]. High concentrations of graphene flakes may increase the possibility of encountering two particles face-to-face, 
thereby decreasing the excluded area effect. Unlike three-dimensional spherical nanoparticles, which only make a point contact that allow them to retain most of their individual surface areas [43], two-dimensional nanomaterials may exhibit more drastic effects.

\subsection{Graphene Surface Accelerates Actin Filament Elongation}

We further investigated the assembly of actin on a graphene surface. We used a graphene layer-transferred flow cell to allow consistent interactions between actin monomers and graphene (see Materials and Methods). Interestingly, the graphene surface significantly enhanced the rates of actin filament elongation $(16.62 \pm 2.05 \mathrm{~nm} / \mathrm{s})$, approximately a $45 \%$ increase compared to those of the control samples (Figure 3).
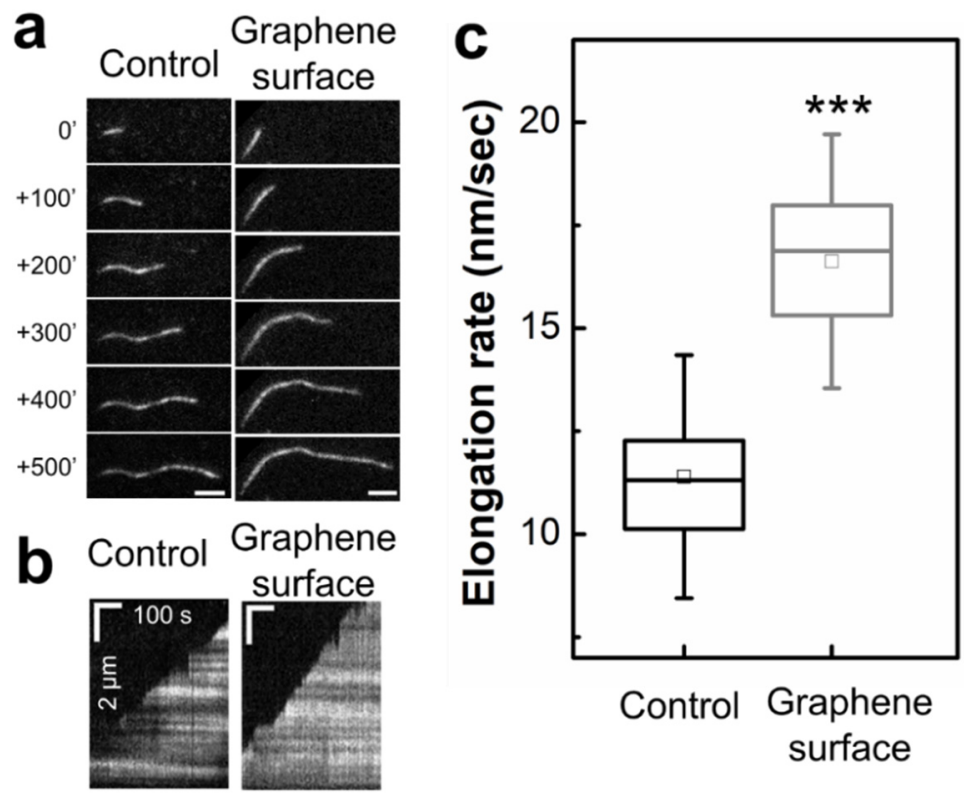

Figure 3. Graphene surface increases the rates of individual actin filament elongation. (a) Representative TIRF microscopy images of growing actin filaments (control or on graphene surface), $\Delta t=100$ s. (b) Linear kymographs of the growing filaments on a graphene surface. Alexa-labeled actin monomers were polymerized in a functionalized flow cell. Images of actin filaments were taken every $5 \mathrm{~s}$. Length scale bar (vertical) is $2 \mu \mathrm{m}$, and time scale bar (horizontal) is $100 \mathrm{~s}$. (c) The rates of actin filament elongation were measured for control samples or for filaments assembled on the graphene surface that was functionalized by pyrenebutyric acid N-hydroxysuccinimide ester (PNHS). The elongation rates were determined by the slope of the actin filament lengths over time, and then converted to a function of time to $\mathrm{nm}$. The box represents the $25-75$ th percentile, whiskers indicate standard deviation (SD), and the middle square is the mean. Statistical analysis was performed using Tukey's test. $N=24-67,{ }^{* * *} ; p<0.001$.

Self-assembly of peptides and proteins into specific organized structures is joined by non-covalent bonds [44]. Self-assembly of biomolecules on the surface of 2D materials can be influenced by the interaction at the interface, which depends on the surface properties, such as hydrophilicity/hydrophobicity, electrostatic interactions, and physical properties including topography and roughness [45]. For example, hydrophobic and rough graphene surfaces accelerated the nucleation of insulin amyloid fibrils compared to hydrophilic and smooth surfaces since fibrils tend to assemble into the adsorbed protein on the surface, resulting in faster fibril formation [46]. In addition, the interaction at the interface should properly maintain the structure and functions of the assembled organizations without any disruptions. Hydrophilic surfaces may allow biomolecules to adsorb more strongly on the surfaces via hydrophilic interactions and hydrogen bonding, which may hamper the assembly of biomolecules. Indeed, two residues in actin (GLU270 and LYS284) can form hydrogen bonds with epoxy groups on GO, resulting in a more stable structure compared 
to pristine graphene [34]. The interaction between GO and two actin dimers is strong enough to dissociate them and induce changes in the secondary structure of actin, thereby disrupting the formation of actin filaments [16]. Thus, interactions with a graphene surface may accelerate actin assembly due to its hydrophobicity.

\subsection{Non-Cytotoxic Graphene Surface Alters Morphology of Mouse Embryo Fibroblasts}

We further evaluated the effects of graphene on cytotoxicity of mouse embryo fibroblast NIH-3T3 cells, which are widely used to determine the effects of materials on cellular behaviors [47,48]. NIH-3T3 cells were treated with graphene flakes or seeded on a graphene surface, and their viability was determined using a WST-1 assay. Our WST-1 assay results showed graphene flakes in the range of $0.5-10 \mu \mathrm{g} / \mathrm{mL}$ were not cytotoxic compared to controls (Figure $4 \mathrm{a}$ ). A total of $20 \mu \mathrm{g} / \mathrm{mL}$ graphene flakes showed significant difference in cell viability (from controls) after $24 \mathrm{~h}$ (Figure $4 \mathrm{a}$ ); however, the cell viability at $48 \mathrm{~h}$ did not show any significant difference, indicating that the highest concentration of graphene flakes $(20 \mu \mathrm{g} / \mathrm{mL})$ is not cytotoxic to NIH-3T3 cells (Figure 4a). Several studies have reported that graphene flakes in suspension could be cytotoxic because they can accumulate and cover the cell surface or form pores on the cell membrane [49,50]. However, our results indicate that graphene flakes have minimal impact on cell viability. The graphene surface also did not show any significant difference with controls (Figure $4 b$ ), which is in good agreement with observations for other cells, such as mouse embryo BALB/3T3 cells and murine fibroblast L929 cells [51,52]. Of note, the cytotoxicity could be varying depending on the cell type. For example, $25 \mu \mathrm{g} / \mathrm{mL}$ of graphene flakes induced cytotoxicity to human skin fibroblasts [50]. A549 cells exhibited cytotoxicity starting from $50 \mu \mathrm{g} / \mathrm{mL}$ of graphene oxide sheets, whereas over $10 \mu \mathrm{g} / \mathrm{mL}$ of graphene oxide sheets were cytotoxic to Raw549 cells [49].
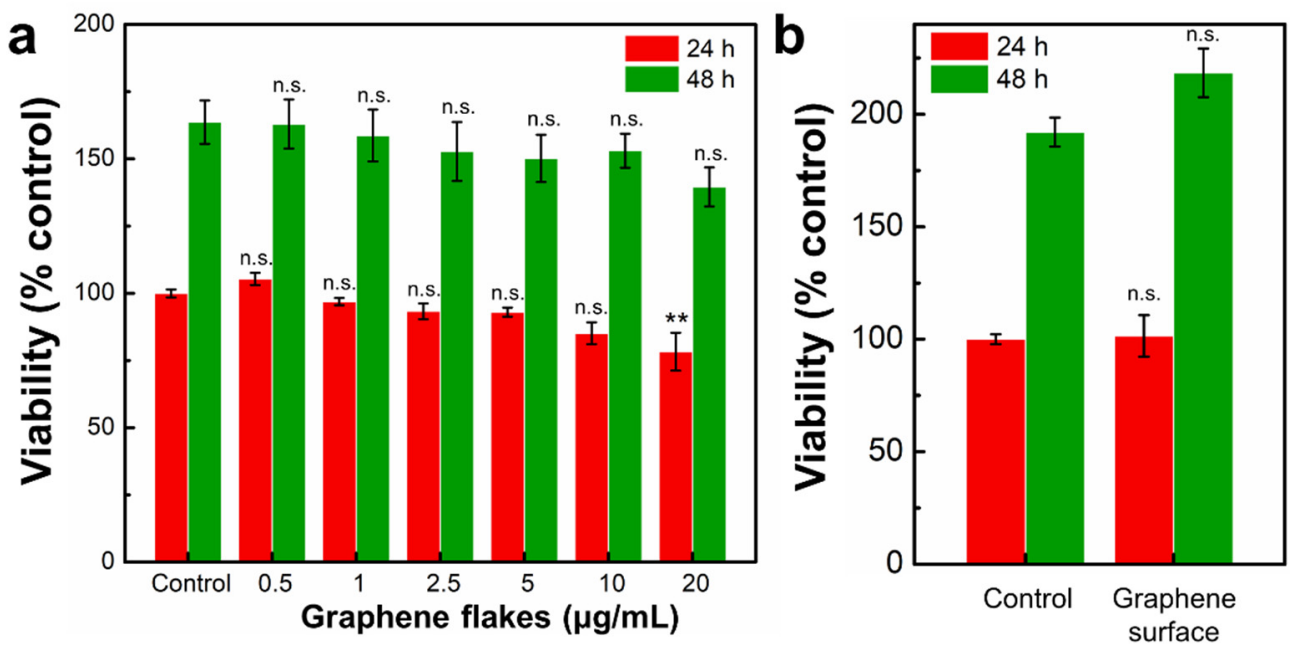

Figure 4. Effects of graphene flakes on viability of NIH-3T3 cells. The viability of NIH-3T3 cells was determined after $24 \mathrm{~h}$ and $48 \mathrm{~h}$ exposure to various concentrations of (a) graphene flakes $(0.5-20 \mu \mathrm{g} / \mathrm{mL})$ or $(\mathbf{b})$ on a graphene surface using a WST-1 assay. The results are expressed as the mean \pm standard deviation (S.D.) of three independent experiments. n.s., not significant; ${ }^{* *}, p<0.01$.

Next, we investigated how graphene affects cell morphology and spreading by visualizing the actin cytoskeleton inside NIH-3T3 cells with optical and confocal microscopy (Figure 5a, Figures S2 and S3). Optical and fluorescence imaging revealed graphene flakes did not induce any morphological changes in NIH-3T3 cells compared with controls (Figure 5a, Figures S2 and S3). In contrast, cells cultured on the graphene surface were observed to be stretched (Figure 5a). We further quantified the stretched cell morphology by analyzing the cell aspect ratio (i.e., ratio between long axis and short axis) as described previously [53] (Figure 5b). The average cell aspect ratio of NIH-3T3 cells without graphene 
was $3.22 \pm 0.82$, which is within the range of the previously reported values $(1.3-3.8)[53,54]$. The average cell aspect ratio in the presence of graphene flakes $(0.5-20 \mu \mathrm{g} / \mathrm{mL})$ did not show significant differences compared to control samples (Figure 5c, Figure S2). Interestingly, cells seeded on the graphene surface exhibited the widest range of cell aspect ratios $(4.83 \pm 2.64)$ (Figure $5 \mathrm{c}$ ). Both highly elongated and unspread cell morphology was reflected in the large standard deviation of the cell aspect ratio. This morphological analysis suggests that interactions with graphene surfaces can modulate cell shapes as well as cell spreading.

a

Phalloidin - Actin

DAPI - Nucleus
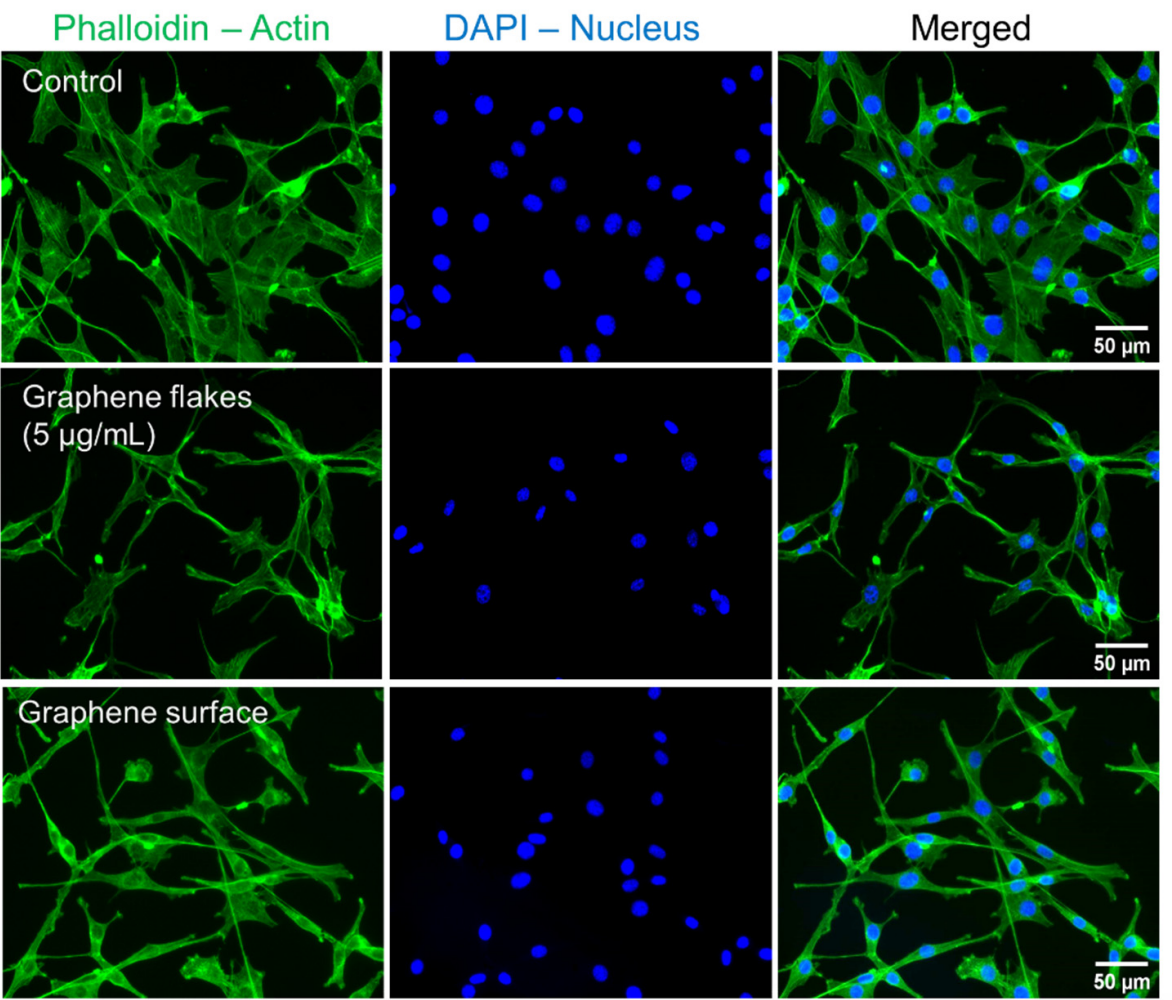

b
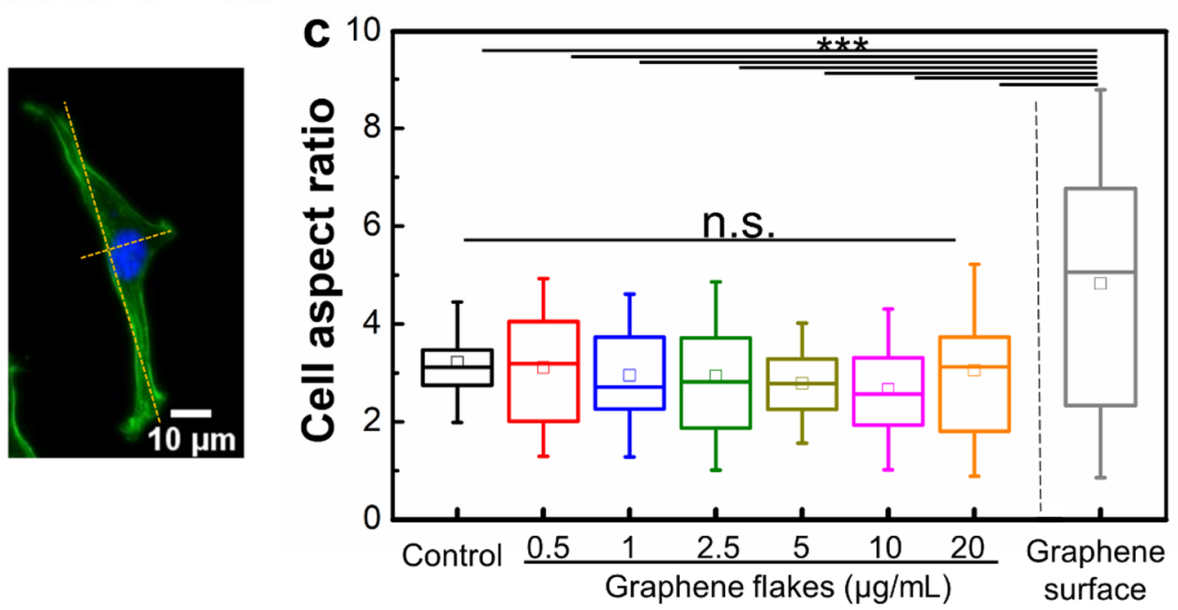

Figure 5. Effects of graphene flakes and graphene surface on NIH-3T3 cell morphology and spreading. (a) NIH-3T3 cells were incubated for $24 \mathrm{~h}$ on either a poly-L-lysine coated coverslip (top), on a polyL-lysine coated coverslip and treated with graphene flakes $(5 \mu \mathrm{g} / \mathrm{mL})$ (middle), or on a pristine graphene monolayer (bottom). Then, cells were stained with Acti-stain 488 phalloidin (actin, green) and DAPI (nucleus, blue). (b) Representative confocal microscopy image of a cell used to measure the cell aspect ratio (major/minor axis). (c) Quantified cell aspect ratio of NIH-3T3 cells incubated with graphene flakes or on a graphene surface. $N=20-73$ across three independent experiments. n.s., not significant; ${ }^{* * *}, p<0.001$. 
Cellular adhesion and spreading can be altered by surface properties, such as topography and wettability (hydrophobicity and hydrophilicity) $[55,56]$. Lee et al. have shown that single graphene layer-transferred glass surfaces exhibit higher nano-roughness compared to glass alone, thereby enhancing the adhesion of human embryo stem cells with increased focal adhesion [57]. Another surface physical factor affecting cell adhesion is hydrophobicity and hydrophilicity of the surface [58]. The water contact angle on a plain glass surface is $42^{\circ}$, while on a graphene layer-transferred glass surface is $67^{\circ}$ [59]. Optimal hydrophobicity is varied and strongly depends on the type of cells. For example, mouse fibroblast $\mathrm{L}$ cells showed maximum cell adhesion on polymer-coated surfaces where the contact angle ranges between $60^{\circ}$ to $80^{\circ}$ [60]. The optimal adhesion of osteosarcoma cells occurs at the water contact angle of siloxane-coated polystyrene, $64^{\circ}$ [61]. These factors may modulate the adhesion of NIH-3T3 cells on graphene layer-transferred glass with morphological changes, evidenced by changes in spreading (Figure 5). The changes in cell spreading and adhesion induced by external physical cues are accompanied with the actin cytoskeleton modulation. Cell spreading is an active process that is controlled by complex mechanisms, including actin polymerization, cell membrane deformation, and interaction at the interface of a cell membrane-substrate [62]. Therefore, it is possible that the regulation of the intracellular cytoskeleton is a result of adaptation to the microenvironment as cells sense and respond to the mechanical features of a graphene surface.

\section{Materials and Methods}

\subsection{Sample Preparation}

Actin was purified from rabbit skeletal muscle acetone powder (Pel-Freeze Biologicals Inc., Rogers, AR, USA) and gel-filtered over Sephacryl S-300 equilibrated in buffer A ( $2 \mathrm{mM}$ Tris- $\mathrm{HCl}, 0.2 \mathrm{mM} \mathrm{CaCl}_{2}, 1 \mathrm{mM} \mathrm{NaN}_{3}, 0.2 \mathrm{mM}$ ATP, $0.5 \mathrm{mM}$ DTT, pH 8.0) as described in [63]. Purified actin was labeled with Alexa-488 succimidyl ester dye (Molecular Probes Inc., Eugene, OR, USA) (the labeling efficiency was $\sim 40 \%$ ) as described in [7]. $\mathrm{Ca}^{2+}$-actin monomers were converted into $\mathrm{Mg}^{2+}$-actin monomers by the addition of $0.2 \mathrm{mM}$ EGTA and $\mathrm{MgCl}_{2}$ with the concentration of actin plus $10 \mu \mathrm{M}$ for $5 \mathrm{~min}$, then $1 / 10$ th volume of $10 \times$ polymerization buffer $(500 \mathrm{mM} \mathrm{KCl}, 20 \mathrm{mM} \mathrm{MgCl} 2,100 \mathrm{mM}$ imidazole, $\mathrm{pH} 7.0,10 \mathrm{mM}$ ATP, and $10 \mathrm{mM}$ DTT) was added and incubated at room temperature $\left(\mathrm{T} \sim 22^{\circ} \mathrm{C}\right)$ for $1 \mathrm{~h}$ as described in [64].

Graphene flakes were purchased from Alfa Aesar Co., Inc. (Tewksbury, MA, USA) (surface area $500 \mathrm{~m}^{2} / \mathrm{g}, 5 \mathrm{~nm}$ thickness, diameter $\sim 2 \mu \mathrm{m}$ ). Graphene flakes were dissolved in $\mathrm{ddH}_{2} \mathrm{O}$ and vortexed for $30 \mathrm{~s}$ before use for in vitro actin polymerization or dissolved in DMEM media for the cell experiment. A pristine graphene sheet $(10 \mathrm{~mm} \times 20 \mathrm{~mm})$ was transferred on a $22 \mathrm{~mm} \times 40 \mathrm{~mm}$ coverslip. Chemical vapor deposition (CVD) graphene grown on copper foil from Grolltex (San Diego, CA, USA) was used. CVD grown monolayer graphene was wet transferred [65] on the cover slip. After the transfer, the samples were annealed in forming gas $\left(90 \% \mathrm{~N}_{2}\right.$ and $\left.10 \% \mathrm{H}_{2}\right)$ ambient at $400{ }^{\circ} \mathrm{C}$ for $3 \mathrm{~h}$ to remove the contaminants on the graphene film.

\subsection{Steady-State TIRF Microscopy Imaging and Data Analysis}

For steady-state imaging, actin monomers (12-18\% Alexa-labeled, $1 \mu \mathrm{M})$ were polymerized by the addition of KMI buffer in the presence of graphene flakes (dissolved in $\mathrm{ddH}_{2} \mathrm{O}$, dilution factor $\times 50$ ) for $1 \mathrm{~h}$ at room temperature. F-actin samples were diluted in optical imaging buffer (10 mM imidazole $\mathrm{pH} 7.0,50 \mathrm{mM} \mathrm{KCl}, 2 \mathrm{mM} \mathrm{MgCl}_{2}, 1 \mathrm{mM}$ ATP, $1 \mathrm{mM}$ DTT, $15 \mathrm{mM}$ glucose, $1 \mathrm{mg} / \mathrm{mL}$ catalase, and $0.2 \mathrm{mg} / \mathrm{mL}$ glucose oxidase) [64,66]. Actin filaments were immobilized on coverslips coated with $0.01 \% v / v$ poly-L-lysine (Sigma-Aldrich, St. Louis, MO, USA), which produces a weak electrostatic force to adhere biopolymers to glass surfaces [66]. F-actin images were acquired at room temperature using a Nikon Eclipse Ti TIRF microscope equipped with a Hamamatsu Image EM X2 CCD camera, 100× oil immersion objective (numerical aperture 1.49), and Nikon LU-N4 laser. Nikon Imaging 
Software (NIS) Elements (ver. 5.02) was used to capture images (pixel size $=0.16 \mu \mathrm{m} / \mathrm{pixel}$ ). F-actin lengths $(L)$ were analyzed using ImageJ, Persistence [67], and OriginLab (ver. 8.5).

\subsection{Pyrene Assay}

Pyrene actin ( $>99 \%$ purity) was purchased from Cytoskeleton Inc. (Denver, CO, USA) and mixed with unlabeled actin monomers to make $20 \%$ labeled pyrene actin. $\mathrm{Ca}^{2+}{ }^{2}$-bound pyrene labeled G-actin was exchanged to $\mathrm{Mg}^{2+}$ as previously described in [68]. Graphene flakes (dissolved in $\mathrm{ddH}_{2} \mathrm{O}$, dilution factor $\times 100$ ) were then added to $\mathrm{Mg}^{2+}$-G-actin. In total, 1/10th volume of $10 \times \mathrm{KMI}$ buffer was rapidly added to pyrene actin $(5 \mu \mathrm{M})$ to start actin polymerization. Pyrene fluorescence was monitored at $407 \mathrm{~nm}$ every $10 \mathrm{~s}$ over $2 \mathrm{~h}$ in a 96-well fluorescence plate reader (SpectraMax Gemini XPS, Molecular Devices LLC, CA, USA) with $360 \mathrm{~nm}$ excitation. Since the graphene surface layer cannot be directly transferred into a 96-well plate, it was not possible to observe pyrene-actin polymerization on the graphene-transferred surface.

\subsection{Flow Cell Preparation and Real-Time TIRF Microscopy Imaging}

Functionalized coverslips were prepared using a modified protocol based on Winterhoff et al. [68,69]. Briefly, coverslips were sonicated at $60{ }^{\circ} \mathrm{C}$ for $45 \min$ in $1 \mathrm{M} \mathrm{KOH}$,

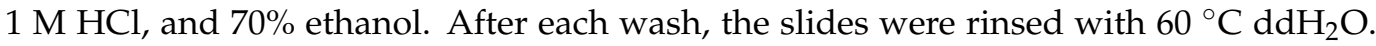
Two functionalization solutions were prepared by using an $80 \%$ ethanol and $1 \% 1 \mathrm{M} \mathrm{HCl}$ solution. In total, $1 \mathrm{mg} / \mathrm{mL}$ solutions of mPEG-silane (MW 2000 Da, Laysan Bio Inc., Arab, AL, USA) and biotin-PEG-silane (MW 3400 Da, Laysan Bio Inc., Arab, AL, USA) were prepared in $80 \%$ ethanol. The solutions were mixed at a ratio of 1:500 of biotin-PEG-silane to mPEG-silane. Coverslips were incubated overnight at $60^{\circ} \mathrm{C}$ in a humid chamber, rinsed with warm water, and dried before using. Then, a flow cell chamber was constructed as described in [69]. A $1 \%(w / v)$ fatty-free BSA solution containing 1\% streptavidin (in 1X KMI buffer) was injected into the flow cell chamber to block unnecessary binding. Images of polymerizing actin (18-20\% Alexa-labeled) were taken every five seconds using a Nikon Eclipse Ti TIRF microscope equipped with a Hamamatsu Orca-Flash 4.0 Digital Camera C13440, 100 $\times$ oil immersion objective (numerical aperture 1.49), and Nikon LU-N4 laser. Nikon Imaging Software (NIS) Elements (ver. 5.02) was used to capture images (pixel size $=0.07 \mu \mathrm{m} /$ pixel).

From the stacks of images of polymerizing actin filaments, we obtained kymographs that showed the changes in fluorescence intensity of the actin filament backbone over the course of time using ImageJ software. We calculated the actin filament growth rates by plotting the time frame versus the elongated filament length, where the slope yields the elongation rate of individual actin filaments [36,69].

A graphene layer-transferred coverslip was functionalized by pyrenebutyric acid $\mathrm{N}$-hydroxysuccinimide ester (PNHS) dissolved in dimethylformaide (DMF) for $24 \mathrm{~h}$ since biotin-PEG was not able to anchor onto the graphene surface due to its hydrophobicity. PNHS can be used as a linker of biomolecules and graphene as the pyrene groups interact with the graphene surface via $\pi-\pi$ stacking while the succinimidyl ester groups react with amines of biomolecules [70,71]. The hydrodynamic radii of PEG mw 3400 for the silane-PEG-biotin is $1.94 \mathrm{~nm}$ [72]. Functionalized graphene surface was washed with DMF and $\mathrm{ddH}_{2} \mathrm{O}$ thoroughly, followed by incubation with the biotin-PEG-silane/mPEG-silane solution (the ratio of biotin-PEG-siline to mPEG-silane 1:500) overnight at $60^{\circ} \mathrm{C}$ in a humid chamber, rinsed with warm water, and dried before using.

\subsection{Cell Culture}

Mouse embryo fibroblast NIH-3T3 cells were purchased from American Type Culture Collection (ATCC; Rockville, MD, USA). NIH-3T3 cells were maintained in Dulbecco's modified Eagle's medium (DMEM) supplemented with $10 \%(v / v)$ Fetal Calf Serum (FCS) and $1 \%$ penicillin/streptomycin in a $5 \% \mathrm{CO}_{2}$ incubator at $37^{\circ} \mathrm{C}$. NIH-3T3 cells were seeded 
in a 6-well culture plate or 96-well culture plate for $24 \mathrm{~h}$. Then, graphene flakes in DMEM containing $10 \%$ FCS and 1\% P/S were treated into cells and incubated up to $48 \mathrm{~h}$.

\subsection{Cell Viability Assay, Cell Imaging, and Morphology Analysis}

Cells were seeded in 96-well plates (Corning Inc., Corning, NY, USA) at a density of $5 \times 10^{3}$ cells/well, with a total volume of $200 \mu \mathrm{L}$. After $24 \mathrm{~h}$, cells were treated with graphene flakes and kept at $37^{\circ} \mathrm{C}$ in a humidified $5 \% \mathrm{CO}_{2}$ incubator. After 24 and $48 \mathrm{~h}$, $20 \mu \mathrm{L}$ of WST-1 reagents (10:1) (Sigma-Aldrich, St. Louis, MO, USA) were supplemented, and cells were incubated for 2 more hours. For the cell viability assay on the graphene surface, cells were seeded on graphene layer-transferred coverslips or poly-L-lysine-coated coverslips $\left(0.01 \% v / v\right.$ poly-L-lysine) as a control in 6-well plates at a density of $1 \times 10^{5}$ cells/well, with a total volume of $2000 \mu \mathrm{L}$. After $24 \mathrm{~h}$ and $48 \mathrm{~h}, 200 \mu \mathrm{L}$ of WST-1 reagents (10:1) (Sigma-Aldrich, St. Louis, MO, USA) were supplemented, and cells were incubated for 2 more hours. Final absorbance of the samples against a background control (medium alone, which also served as a blank) was measured at $450 \mathrm{~nm}$ and $630 \mathrm{~nm}$ using a SpectraMax i3x (Molecular Devices, Sunnyvale, CA, USA).

Cells were seeded at a density of $1 \times 10^{5}$ cells/well onto coverslips coated with poly-L-lysine $(0.01 \% v / v)$ in a 6-well cell culture plate. After $24 \mathrm{~h}$, cells were treated with graphene flakes $(0.5-20 \mu \mathrm{g} / \mathrm{mL})$ for $24-48 \mathrm{~h}$. Cells were also seeded at the same density onto graphene-layer transferred coverslips and incubated for $24 \mathrm{~h}$. Bright field microscopy images of cells were obtained using TS2 inverted microscopy (Nikon, Tokyo, Japan) at $24 \mathrm{~h}$ and $48 \mathrm{~h}$ after treatment. Prior to obtaining fluorescence microscopy images, cells were fixed with $4 \%$ paraformaldehyde for $10 \mathrm{~min}$. The fixed cells were then permeabilized for 5 min with $0.1 \%$ Triton X-100 in PBS. Coverslips were rinsed with PBS and incubated for 30 min with Acti-stain 488 Phalloidin (Cytoskeleton Inc., Denver, CO, USA). Following a PBS wash, the coverslips were incubated for 5 min with DAPI (Cytoskeleton Inc., Denver, CO, USA) for counterstaining. Fluorescent images were collected with a BZ-X800 confocal microscope (Keyence, Itasca, IL, USA). To quantify the morphology of stretched cells, the aspect ratios (major axis/minor axis) of cells were measured using the ImageJ program [53].

\subsection{Statistical Analysis}

Statistical significance of the numbers of filaments per bundle, bundle persistence lengths, and bundle diameters was determined using OriginLab ver. 8.5 software by conducting multiple analysis of variance (ANOVA) with post-hoc Tukey's test. Notation for probability ( $p$-value): n.s., not significant $(p>0.05) ;{ }^{*}, p<0.05 ;{ }^{* *}, p<0.01 ;{ }^{* * *}, p<0.001$.

\section{Conclusions}

Here, we report the effects of graphene flakes and a graphene surface on actin filament assembly kinetics and NIH-3T3 fibroblast cell spreading as well as morphology. Direct visualization of individual actin filament assembly in real-time demonstrates that both graphene flakes and a graphene surface significantly enhance the rates of actin filament elongation. Cell culture experiment results show that graphene flake uptake does not incur cytotoxicity. Further, interactions with a graphene surface lead to changes in NIH-3T3 cell spreading and stretched cell morphology, which may be related to the enhanced actin filament assembly kinetics. Our work suggests that interaction/interface with graphene may have a direct impact on the actin cytoskeleton remodeling at the molecular level, possibly modulating cell motility and physiology.

Supplementary Materials: The following are available online at https:/ / www.mdpi.com/article/10 .3390/ijms23010509/s1.

Author Contributions: J.P. and E.H.K. designed the research; J.P., P.K. and A.K. performed experiments; J.P., P.K. and E.H.K. analyzed data; J.P., A.K., P.K., T.R. and E.H.K. wrote and revised the paper. All authors have read and agreed to the published version of the manuscript. 
Funding: Research reported in this study was supported by the National Science Foundation under Grant No. 1943266 (to E.H.K), the National Institute of Allergy and Infectious Disease of the NIH under Award No. R01AI139242, and funds from the University of Central Florida (UCF) awarded to E.H.K., and by the National Science Foundation Grant No. 1845331 to T.R.

Institutional Review Board Statement: Not applicable.

Informed Consent Statement: Not applicable.

Data Availability Statement: Not applicable.

Acknowledgments: We are grateful to Nicholas Castaneda for proofreading the manuscript and providing valuable comments. We acknowledge UCF Nanoscience Technology Center for shared equipment and the cell culture room. We thank Santra group for allowing us to use the plate reader. We are thankful to Kang group members for their continued support.

Conflicts of Interest: The authors declare no conflict of interest.

\section{References}

1. Blanchoin, L.; Boujemaa-Paterski, R.; Sykes, C.; Plastino, J. Actin dynamics, architecture, and mechanics in cell motility. Physiol. Rev. 2014, 94, 235-263. [CrossRef] [PubMed]

2. Fletcher, D.A.; Mullins, R.D. Cell mechanics and the cytoskeleton. Nature 2010, 463, 485-492. [CrossRef] [PubMed]

3. Pollard, T.D.; Cooper, J.A. Actin, a central player in cell shape and movement. Science 2009, 326, 1208-1212. [CrossRef] [PubMed]

4. Scipion, C.P.M.; Ghoshdastider, U.; Ferrer, F.J.; Yuen, T.-Y.; Wongsantichon, J.; Robinson, R.C. Structural evidence for the roles of divalent cations in actin polymerization and activation of ATP hydrolysis. Proc. Natl. Acad. Sci. USA 2018, 115, 10345-10350. [CrossRef]

5. Dominguez, R.; Holmes, K.C. Actin structure and function. Annu. Rev. Biophys. 2011, 40, 169-186. [CrossRef]

6. Pollard, T.D. Actin and actin-binding proteins. Cold Spring Harb. Perspect. Biol. 2016, 8, a018226. [CrossRef]

7. Kang, H.; Bradley, M.J.; McCullough, B.R.; Pierre, A.; Grintsevich, E.E.; Reisler, E.; de la Cruz, E.M. Identification of cation-binding sites on actin that drive polymerization and modulate bending stiffness. Proc. Natl. Acad. Sci. USA 2012, 109, 16923-16927. [CrossRef]

8. Kang, H.; Bradley, M.J.; Cao, W.; Zhou, K.; Grintsevich, E.E.; Michelot, A.; Sindelar, C.V.; Hochstrasser, M.; Enrique, M. Site-specific cation release drives actin filament severing by vertebrate cofilin. Proc. Natl. Acad. Sci. USA 2014, 111, 17821-17826. [CrossRef] [PubMed]

9. Kuznetsova, I.M.; Turoverov, K.K.; Uversky, V.N. What macromolecular crowding can do to a protein. Int. J. Mol. Sci. 2014, 15, 23090-23140. [CrossRef]

10. Frederick, K.B.; Sept, D.; de la Cruz, E.M. Effects of solution crowding on actin polymerization reveal the energetic basis for nucleotide-dependent filament stability. J. Mol. Biol. 2008, 378, 540-550. [CrossRef]

11. Rosin, C.; Estel, K.; Halker, J.; Winter, R. Combined effects of temperature, pressure, and co-solvents on the polymerization kinetics of actin. ChemPhysChem 2015, 16, 1379-1385. [CrossRef]

12. Pernier, J.; Shekhar, S.; Jegou, A.; Guichard, B.; Carlier, M.-F. Profilin interaction with actin filament barbed end controls dynamic instability, capping, branching, and motility. Dev. Cell 2016, 36, 201-214. [CrossRef]

13. Ghosh, M.; Song, X.; Mouneimne, G.; Sidani, M.; Lawrence, D.S.; Condeelis, J.S. Cofilin promotes actin polymerization and defines the direction of cell motility. Science 2004, 304, 743-746. [CrossRef] [PubMed]

14. Dong, Y.; Sun, H.; Li, X.; Li, X.; Zhao, L. Impact of carbon nanomaterials on actin polymerization. J. Nanosci. Nanotechnol. 2016, 16, 2408-2417. [CrossRef]

15. Holt, B.D.; Shams, H.; Horst, T.A.; Basu, S.; Rape, A.D.; Wang, Y.-L.; Rohde, G.K.; Mofrad, M.R.K.; Islam, M.F.; Dahl, K.N. Altered cell mechanics from the inside: Dispersed single wall carbon nanotubes integrate with and restructure actin. J. Funct. Biomater. 2012, 3, 398-417. [CrossRef] [PubMed]

16. Tian, X.; Yang, Z.; Duan, G.; Wu, A.; Gu, Z.; Zhang, L.; Chen, C.; Chai, Z.; Ge, C.; Zhou, R. Graphene oxide nanosheets retard cellular migration via disruption of actin cytoskeleton. Small 2017, 13, 1602133. [CrossRef]

17. Ghorbani, M.; Soleymani, H.; Hashemzadeh, H.; Mortezazadeh, S.; Sedghi, M.; Shojaeilangari, S.; Allahverdi, A.; Naderi-Manesh, $\mathrm{H}$. Microfluidic investigation of the effect of graphene oxide on mechanical properties of cell and actin cytoskeleton networks: Experimental and theoretical approaches. Sci. Rep. 2021, 11, 16216. [CrossRef]

18. Holt, B.D.; Short, P.A.; Rape, A.D.; Wang, Y.-L.; Islam, M.F.; Dahl, K.N. Carbon nanotubes reorganize actin structures in cells and ex vivo. ACS Nano 2010, 4, 4872-4878. [CrossRef]

19. Hamzah, A.A.; Selvarajan, R.S.; Majlis, B. Graphene for biomedical applications: A review. Sains Malays. 2017, 46, 1125-1139. [CrossRef]

20. Zhu, Y.; Murali, S.; Cai, W.; Li, X.; Suk, J.W.; Potts, J.R.; Ruoff, R.S. Graphene and graphene oxide: Synthesis, properties, and applications. Adv. Mater. 2010, 22, 3906-3924. [CrossRef]

21. Avouris, P. Graphene: Electronic and photonic properties and devices. Nano Lett. 2010, 10, 4285-4294. [CrossRef] 
22. Papageorgiou, D.G.; Kinloch, I.A.; Young, R.J. Mechanical properties of graphene and graphene-based nanocomposites. Prog. Mater. Sci. 2017, 90, 75-127. [CrossRef]

23. Liao, C.; Li, Y.; Tjong, S.C. Graphene nanomaterials: Synthesis, biocompatibility, and cytotoxicity. Int. J. Mol. Sci. 2018, 19, 3564 [CrossRef] [PubMed]

24. Syama, S.; Mohanan, P.V. Safety and biocompatibility of graphene: A new generation nanomaterial for biomedical application. Int. J. Biol. Macromol. 2016, 86, 546-555. [CrossRef] [PubMed]

25. Kumar, S.; Parekh, S.H. Linking graphene-based material physicochemical properties with molecular adsorption, structure and cell fate. Commun. Chem. 2020, 3, 8. [CrossRef]

26. Iannazzo, D.; Pistone, A.; Salamò, M.; Galvagno, S.; Romeo, R.; Giofré, S.V.; Branca, C.; Visalli, G.; di Pietro, A. Graphene quantum dots for cancer targeted drug delivery. Int. J. Pharm. 2017, 518, 185-192. [CrossRef]

27. Bai, Y.; Xu, T.; Zhang, X. Graphene-based biosensors for detection of biomarkers. Micromachines 2020, 11, 60. [CrossRef]

28. Rahman, M.; Ahmad, M.Z.; Ahmad, J.; Firdous, J.; Ahmad, F.J.; Mushtaq, G.; Kamal, M.A.; Akhter, S. Role of graphene nanocomposites in cancer therapy: Theranostic applications, metabolic fate and toxicity issues. Curr. Drug Metab. 2015, 16, 397-409. [CrossRef]

29. Feng, L.; Wu, L.; Qu, X. New horizons for diagnostics and therapeutic applications of graphene and graphene oxide. Adv. Mater. 2013, 25, 168-186. [CrossRef]

30. Zhou, H.; Zhao, K.; Li, W.; Yang, N.; Liu, Y.; Chen, C.; Wei, T. The interactions between pristine graphene and macrophages and the production of cytokines/chemokines via TLR- and NF- $\kappa$ B-related signaling pathways. Biomaterials 2012, 33, 6933-6942. [CrossRef] [PubMed]

31. Sasidharan, A.; Panchakarla, L.S.; Chandran, P.; Menon, D.; Nair, S.; Rao, C.N.R.; Koyakutty, M. Differential nano-bio interactions and toxicity effects of pristine versus functionalized graphene. Nanoscale 2011, 3, 2461-2464. [CrossRef] [PubMed]

32. Mukhopadhyay, A.; Basu, S.; Singha, S.; Patra, H.K. Inner-view of nanomaterial incited protein conformational changes: Insights into designable interaction. Research 2018, 2018, 9712832. [CrossRef] [PubMed]

33. Zhou, H.; Zhang, B.; Zheng, J.; Yu, M.; Zhou, T.; Zhao, K.; Jia, Y.; Gao, X.; Chen, C.; Wei, T. The inhibition of migration and invasion of cancer cells by graphene via the impairment of mitochondrial respiration. Biomaterials 2014, 35, 1597-1607. [CrossRef]

34. Li, T.; Oloyede, A.; Gu, Y. Adhesive characteristics of low dimensional carbon nanomaterial on actin. Appl. Phys. Lett. 2014, 104, 023702. [CrossRef]

35. Kuziel, A.W.; Milowska, K.Z.; Chau, P.-L.; Boncel, S.; Koziol, K.K.; Yahya, N.; Payne, M.C. The true amphipathic nature of graphene flakes: A versatile 2D stabilizer. Adv. Mater. 2020, 32, 2000608. [CrossRef]

36. Kuhn, J.R.; Pollard, T.D. Real-time measurements of actin filament polymerization by total internal reflection fluorescence microscopy. Biophys. J. 2005, 88, 1387-1402. [CrossRef]

37. Korn, E.D.; Carlier, M.-F.; Pantaloni, D. Actin polymerization and ATP hydrolysis. Science 1987, 238, 638-644. [CrossRef]

38. Pollard, T.D.; Blanchoin, L.; Mullins, R.D. Molecular mechanisms controlling actin filament dynamics in nonmuscle cells. Annu. Rev. Biophys. Biomol. Struct. 2000, 29, 545-576. [CrossRef]

39. Minton, A.P. Implications of macromolecular crowding for protein assembly. Curr. Opin. Struct. Biol. 2000, 10, 34-39. [CrossRef]

40. Minton, A.P. The influence of macromolecular crowding and macromolecular confinement on biochemical reactions in physiological media. J. Biol. Chem. 2001, 276, 10577-10580. [CrossRef]

41. Rashid, R.; Chee, S.M.L.; Raghunath, M.; Wohland, T. Macromolecular crowding gives rise to microviscosity, anomalous diffusion and accelerated actin polymerization. Phys. Biol. 2015, 12, 034001. [CrossRef]

42. Geigenfeind, T.; Heras, D.D.L. Principal component analysis of the excluded area of two-dimensional hard particles. J. Chem. Phys. 2019, 150, 184906. [CrossRef] [PubMed]

43. Sanchez, V.C.; Jachak, A.; Hurt, R.H.; Kane, A.B. Biological interactions of graphene-family nanomaterials: An interdisciplinary review. Chem. Res. Toxicol. 2012, 25, 15-34. [CrossRef] [PubMed]

44. Whitesides, G.M.; Mathias, J.P.; Seto, C.T. Molecular self-assembly and nanochemistry: A chemical strategy for the synthesis of nanostructures. Science 1991, 254, 1312-1319. [CrossRef] [PubMed]

45. Yang, B.; Adams, D.J.; Marlow, M.; Zelzer, M. Surface-mediated supramolecular self-assembly of protein, peptide, and nucleoside derivatives: From surface design to the underlying mechanism and tailored functions. Langmuir 2018, 34, 15109-15125. [CrossRef]

46. Nayak, A.; Dutta, A.K.; Belfort, G. Surface-enhanced nucleation of insulin amyloid fibrillation. Biochem. Biophys. Res. Commun. 2008, 369, 303-307. [CrossRef]

47. Ryoo, S.R.; Kim, Y.K.; Kim, M.H.; Min, D.H. Behaviors of NIH-3T3 fibroblasts on graphene/carbon nanotubes: Proliferation, focal adhesion, and gene transfection studies. ACS Nano 2010, 4, 6587-6598. [CrossRef]

48. Lin, F.; Du, F.; Huang, J.; Chau, A.; Zhou, Y.; Duan, H.; Wang, J.; Xiong, C. Substrate effect modulates adhesion and proliferation of fibroblast on graphene layer. Colloids Surf. B Biointerfaces 2016, 146, 785-793. [CrossRef]

49. Duan, G.; Zhang, Y.; Luan, B.; Weber, J.K.; Zhou, R.W.; Yang, Z.; Zhao, L.; Xu, J.; Luo, J.; Zhou, R. Graphene-Induced pore formation on cell membranes. Sci. Rep. 2017, 7, 42767. [CrossRef]

50. Liao, K.-H.; Lin, Y.-S.; Macosko, C.W.; Haynes, C.L. Cytotoxicity of graphene oxide and graphene in human erythrocytes and skin fibroblasts. ACS Appl. Mater. Interfaces 2011, 3, 2607-2615. [CrossRef] 
51. Lasocka, I.; Szulc-Dabrowska, L.; Skibniewski, M.; Skibniewska, E.; Gregorczyk-Zboroch, K.; Pasternak, I.; Hubalek Kalbacova, M. Cytocompatibility of graphene monolayer and its impact on focal cell adhesion, mitochondrial morphology and activity in BALB/3T3 fibroblasts. Materials 2021, 14, 643. [CrossRef] [PubMed]

52. Lasocka, I.; Szulc-Dabrowska, L.; Skibniewski, M.; Skibniewska, E.; Strupinski, W.; Pasternak, I.; Kmiec, H.; Kowalczyk, P. Biocompatibility of pristine graphene monolayer: Scaffold for fibroblasts. Toxicol. In Vitro 2018, 48, 276-285. [CrossRef]

53. Zhang, K.; Arranja, A.; Chen, H.; Mytnyk, S.; Wang, Y.; Oldenhof, S.; van Esch, J.H.; Mendes, E. A nano-fibrous platform of copolymer patterned surfaces for controlled cell alignment. RSC Adv. 2018, 8, 21777-21785. [CrossRef]

54. Mancia, A.; Elliott, J.T.; Halter, M.; Bhadriraju, K.; Tona, A.; Spurlin, T.A.; Middlebrooks, B.L.; Baatz, J.E.; Warr, G.W.; Plant, A.L. Quantitative methods to characterize morphological properties of cell lines. Biotechnol. Prog. 2012, 28, 1069-1078. [CrossRef]

55. Jeong, J.-T.; Choi, M.-K.; Sim, Y.; Lim, J.-T.; Kim, G.-S.; Seong, M.-J.; Hyung, J.-H.; Kim, K.S.; Umar, A.; Lee, S.-K. Effect of graphene oxide ratio on the cell adhesion and growth behavior on a graphene oxide-coated silicon substrate. Sci. Rep. 2016, 6, 33835. [CrossRef]

56. Kim, D.-H.; Han, K.; Gupta, K.; Kwon, K.W.; Suh, K.-Y.; Levchenko, A. Mechanosensitivity of fibroblast cell shape and movement to anisotropic substratum topography gradients. Biomaterials 2009, 30, 5433-5444. [CrossRef] [PubMed]

57. Lee, T.-J.; Park, S.; Bhang, S.H.; Yoon, J.-K.; Jo, I.; Jeong, G.-J.; Hong, B.H.; Kim, B.-S. Graphene enhances the cardiomyogenic differentiation of human embryonic stem cells. Biochem. Biophys. Res. Commun. 2014, 452, 174-180. [CrossRef]

58. Ayala, R.; Zhang, C.; Yang, D.; Hwang, Y.; Aung, A.; Shroff, S.S.; Arce, F.T.; Lal, R.; Arya, G.; Varghese, S. Engineering the cellmaterial interface for controlling stem cell adhesion, migration, and differentiation. Biomaterials 2011, 32, 3700-3711. [CrossRef] [PubMed]

59. Yilbas, B.S.; Ibrahim, A.; Ali, H.; Khaled, M.; Laoui, T. Hydrophobic and optical characteristics of graphene and graphene oxide films transferred onto functionalized silica particles deposited glass surface. Appl. Surf. Sci. 2018, 442, 213-223. [CrossRef]

60. Tamada, Y.; Ikada, Y. Effect of preadsorbed proteins on cell adhesion to polymer surfaces. J. Colloid Interface Sci. 1993, 155, 334-339. [CrossRef]

61. Dowling, D.P.; Miller, I.S.; Ardhaoui, M.; Gallagher, W.M. Effect of surface wettability and topography on the adhesion of osteosarcoma cells on plasma-modified polystyrene. J. Biomater. Appl. 2011, 26, 327-347. [CrossRef]

62. McGrath, J.L. Cell spreading: The power to simplify. Curr. Biol. 2007, 17, R357-R358. [CrossRef] [PubMed]

63. Spudich, J.A.; Watt, S. The regulation of rabbit skeletal muscle contraction. I. Biochemical studies of the interaction of the tropomyosin-troponin complex with actin and the proteolytic fragments of myosin. J. Biol. Chem. 1971, 246, 4866-4871. [CrossRef]

64. Castaneda, N.; Lee, M.; Rivera-Jacquez, H.J.; Marracino, R.R.; Merlino, T.R.; Kang, H. Actin filament mechanics and structure in crowded environments. J. Phys. Chem. B 2019, 123, 2770-2779. [CrossRef]

65. Chan, J.; Venugopal, A.; Pirkle, A.; McDonnell, S.; Hinojos, D.; Magnuson, C.W.; Ruoff, R.S.; Colombo, L.; Wallace, R.M.; Vogel, E.M. Reducing extrinsic performance-limiting factors in graphene grown by chemical vapor deposition. ACS Nano 2012, 6 , 3224-3229. [CrossRef]

66. Castaneda, N.; Zheng, T.; Rivera-Jacquez, H.J.; Lee, H.J.; Hyun, J.; Balaeff, A.; Huo, Q.; Kang, H. Cations modulate actin bundle mechanics, assembly dynamics, and structure. J. Phys. Chem. B 2018, 122, 3826-3835. [CrossRef] [PubMed]

67. Graham, J.S.; McCullough, B.R.; Kang, H.; Elam, W.A.; Cao, W.; de la Cruz, E.M. Multi-platform compatible software for analysis of polymer bending mechanics. PLoS ONE 2014, 9, e94766. [CrossRef] [PubMed]

68. Heidings, J.B.; Demosthene, B.; Merlino, T.R.; Castaneda, N.; Kang, E.H. Gelsolin-mediated actin filament severing in crowded environments. Biochem. Biophys. Res. Commun. 2020, 532, 548-554. [CrossRef]

69. Winterhoff, M.; Brühmann, S.; Franke, C.; Breitsprecher, D.; Faix, J. Visualization of Actin Assembly and Filament Turnover by In Vitro Multicolor TIRF Microscopy. In Chemotaxis: Methods and Protocols; Jin, T., Hereld, D., Eds.; Springer: New York, NY, USA, 2016; pp. 287-306.

70. Jiang, Z.; Feng, B.; Xu, J.; Qing, T.; Zhang, P.; Qing, Z. Graphene biosensors for bacterial and viral pathogens. Biosens. Bioelectron. 2020, 166, 112471. [CrossRef]

71. Li, D.; Zhang, W.; Yu, X.; Wang, Z.; Su, Z.; Wei, G. When biomolecules meet graphene: From molecular level interactions to material design and applications. Nanoscale 2016, 8, 19491-19509. [CrossRef]

72. Piguet, F.; Ouldali, H.; Discala, F.; Breton, M.-F.; Behrends, J.C.; Pelta, J.; Oukhaled, A. High temperature extends the range of size discrimination of nonionic polymers by a biological nanopore. Sci. Rep. 2016, 6, 38675. [CrossRef] [PubMed] 